\title{
ERRATUM
}

\section{Gene therapy approach to FAP: in vivo influence of T119M in TTR deposition in a transgenic V30M mouse model}

AR Batista, D Gianni, M Ventosa, AV Coelho, MR Almeida, M Sena-Esteves and MJ Saraiva

Gene Therapy (2014) 21, 1065. doi:10.1038/gt.2014.111

Correction to: Gene Therapy advance online publication 2 October 2014; doi:10.1038/gt.2014.86

This article was published online as Open Access in error. The Open Access information in relation to this article has now been amended and the revised article appears as a Non-Open Access article together with this erratum.

The publisher apologises for this error and any inconvenience it may have caused. 